\section{Pecan Nutrient Element Status and Orchard Soil Fertility in the Southeastern Coastal Plain of the United States}

\author{
M. Lenny Wells ${ }^{1}$
}

AdDITIONAL INDEX wORDs. Carya illinoinensis, fertilizer, leaf analysis, management, soil health

SUMMARY. This survey addresses the current nutritional status of orchards typical of a large portion of the United States pecan (Carya illinoinensis) industry. A leaf nutrition and soil fertility survey was conducted for commercial orchards in a major production area of the U.S. pecan belt, which is located in southern Georgia. The study sampled pecan orchards from 18 July to 5 Aug. 2005 and 17 July to 3 Aug. 2008. All orchards had a history of commercial level orchard management, and represented a wide range of orchards typical of the region. Results indicate that southeastern U.S. pecan producers should focus their nutrient inputs on nitrogen $(\mathrm{N})$, potassium $(\mathrm{K})$, sulfur $(\mathrm{S})$, and copper $(\mathrm{Cu})$ as needed. The survey results show that leaf $\mathrm{N}$ can vary widely by season and among orchard locations. Evidence indicates that many growers could likely forego the soil application of phosphorous $(P)$ and zinc $(\mathrm{Zn})$ until leaf or soil analysis indicates a need. Orchard soil organic matter (SOM) in 2008 averaged $3.63 \%$, and ranged from $1.74 \%$ on coarse-textured sandy soils to $5 \%$ on sandy loam soils. Both SOM and soil nitrate-N were higher in orchards using clover (Trifolium spp.) as a cool-season orchard groundcover than those using a grass sod only. The mean carbon:S ratio of Georgia pecan orchard soils was 504:1, which may further reduce tree uptake of $S$ from low-S soils.

$\mathrm{T}$ The southeastern coastal plain of the United States accounts for $\approx 35 \%$ to $\approx 45 \%$ of United States pecan production, depending upon the year. Pecan trees and orchards typically alternate between years with a heavy nut crop load, the "on" year $(\mathrm{ON})$, followed by a lighter crop load the following year, the "off” year (OFF). Georgia's annual production comprises about $70 \%$ of the total southeastern U.S. pecan production (U.S. Department of Agriculture, 2008). The region's climate is typified by warm, humid conditions and an average of $>30$ inches of rainfall per year. Regional conditions can have a significant effect on crop management practices, tree nutritional status, and orchard soil fertility, all of which affect crop production. As a result, it is of value to recognize the status of pecan tree and orchard soil nutrition typical of a region.

Leaf analysis is widely regarded as a reliable index for many of the nutrient elements of pecan trees. Critical ranges for leaf nutrients have been established based on a specific index tissue sampled at mid-growing season

Department of Horticulture, University of Georgia, 4604 Research Way, Tifton, GA 31793

1'Corresponding author. E-mail: lwells@uga.edu.
(Pond et al., 2006; Smith, 1991; Wells, 2007). The lowest leaf concentration of the critical range represents the smallest leaf concentration that produces maximum yield. Higher concentrations within the critical range neither positively nor negatively impact yield.

Critical leaf sufficiency ranges vary considerably by geographic region and state extension service recommendations (Pond et al., 2006). Crop load (Acuna-Maldonado et al., 2003; Kraimer et al., 2001, 2004; Smith et al., 2007), soil type, and environmental conditions (Johnson and Raun, 2003) can affect nutrient availability, uptake, and/or tissue concentration. Pond et al. (2006) suggest that regional nutrient sufficiency ranges should be considered to ensure accurate nutritional diagnoses.

Although leaf analysis is the primary tool used to make fertilizer recommendations for pecan, soil analysis is also useful in making determinations regarding nutrient availability, interactions, and predictions of potential problems. Soil analysis also reveals information relative to soil health. Soil organic matter levels in pecan orchards have received little attention. Organic matter can enhance soil productivity in many ways, including increased water-holding capacity, chelation of micronutrients, increased nutrient availability via enhancement of mineralization, improved retention of potassium $(\mathrm{K})$, calcium $(\mathrm{Ca})$, and magnesium $(\mathrm{Mg})$, and buffering of soil pH (Brady, 1974). Soil organic matter levels are often enhanced by usage of cover crops and the application of livestock manure as a fertilizer source. Both methods are commonly used by southeastern U.S. pecan producers.

Leaf and soil nutritional surveys are useful ways to assess crop fertility status in a given region, thus providing practitioners with insight into what nutrient management challenges and limitations may exist. This study addresses the current nutritional status of commercial pecan tree and orchard soils typical of the southeastern portion of the U.S. pecan belt.

\section{Materials and methods}

A leaf nutrition and soil fertility survey of pecan orchards was conducted from 18 July to 5 Aug. 2005 and from 17 July to 3 Aug. 2008. In 2005,29 orchards in 15 counties across the Georgia section of the southeastern U.S. pecan belt were sampled (Table 1 ). This is a key region of commercial pecan production and typifies conditions observed throughout much of the southeastern U.S. coastal plain. Orchards in the 15- to 25-year-old range were chosen for the survey based on having typical commercial-level management (Wells, 2007). 'Desirable' trees were sampled in all orchards, except one, in which 'Cape Fear' was sampled. In 2008, 17 mature (15 to 70 years old) pecan

\begin{tabular}{llll}
\hline $\begin{array}{l}\text { Units } \\
\begin{array}{l}\text { To convert U.S. to SI, } \\
\text { multiply by }\end{array}\end{array}$ & U.S. unit & SI unit & $\begin{array}{l}\text { To convert SI to U.S., } \\
\text { multiply by }\end{array}$ \\
\hline 2.54 & inch(es) & $\mathrm{cm}$ & 0.3937 \\
0.4536 & $\mathrm{lb}$ & $\mathrm{kg}$ & 2.2046 \\
1.1209 & $\mathrm{lb} / \mathrm{acre}$ & $\mathrm{kg} \cdot \mathrm{ha}^{-1}$ & 0.8922 \\
1 & $\mathrm{ppm}$ & $\mathrm{mg} \cdot \mathrm{kg}^{-1}$ & 1 \\
$\left({ }^{\circ} \mathrm{F}-32\right) \div 1.8$ & ${ }^{\circ} \mathrm{F}$ & ${ }^{\circ} \mathrm{C}$ & $\left(1.8 \times{ }^{\circ} \mathrm{C}\right)+32$
\end{tabular}


Table 1. Cultivar, soil type, irrigation method, and groundcover between tree rows for sampled pecan orchards in 2005 .

\begin{tabular}{|c|c|c|c|c|}
\hline Orchard & Cultivar & Soil type & $\begin{array}{c}\text { Irrigation } \\
\text { method }^{\mathrm{z}}\end{array}$ & Ground cover ${ }^{\mathrm{y}}$ \\
\hline A & Desirable & Faceville & Drip & Sod \\
\hline B & Desirable & Faceville & Drip & Sod \\
\hline $\mathrm{C}$ & Desirable & Faceville & Drip & Sod \\
\hline $\mathrm{D}$ & Desirable & Greenville & Drip & Sod \\
\hline $\mathrm{E}$ & Desirable & Dothan & Drip & Sod \\
\hline $\mathrm{F}$ & Desirable & Orangeburg & Drip & Sod \\
\hline G & Desirable & Orangeburg & Drip & Sod \\
\hline $\mathrm{H}$ & Desirable & Tifton & Drip & Sod \\
\hline I & Desirable & Greenville & Drip & Sod \\
\hline $\mathrm{J}$ & Desirable & Tifton & Drip & Sod \\
\hline $\mathrm{K}$ & Desirable & Orangeburg & SS & Sod/clover \\
\hline $\mathrm{L}$ & Desirable & Red Bay & SS & Sod/clover \\
\hline M & Desirable & Orangeburg & Drip & Sod \\
\hline $\mathrm{N}$ & Desirable & Tifton & Drip & Sod \\
\hline $\mathrm{O}$ & Desirable & Norfolk & Drip & Sod \\
\hline $\mathrm{P}$ & Desirable & Clarendon & Drip & Sod \\
\hline Q & Desirable & Fuquay & Drip & Sod/clover \\
\hline $\mathrm{R}$ & Desirable & Tifton & Drip & Sod \\
\hline$S$ & Desirable & Fuquay & Drip & Sod \\
\hline $\mathrm{T}$ & Desirable & Lucy Loam & Drip & Sod \\
\hline $\mathrm{U}$ & Desirable & Orangeburg & Drip & Sod \\
\hline $\mathrm{V}$ & Desirable & Fuquay & Drip & Sod \\
\hline W & Desirable & Tifton & Drip & Sod \\
\hline $\mathrm{X}$ & Cape Fear & Tifton & Drip & Sod/clover \\
\hline $\mathrm{Y}$ & Desirable & Tifton & Drip & Sod \\
\hline $\mathrm{Z}$ & Desirable & Tifton & Drip & Sod \\
\hline AA & Desirable & Tifton & Drip & Sod \\
\hline $\mathrm{BB}$ & Desirable & Dothan & Drip & Sod \\
\hline $\mathrm{CC}$ & Desirable & Tifton & Drip & Sod \\
\hline
\end{tabular}

${ }^{\mathrm{z}}$ Drip $=$ drip irrigation, $\mathrm{SS}=$ solid-set sprinkler irrigation.

y'Sod = bermudagrass; Clover $=$ crimson clover, ball clover, or 'Durana' white clover.

orchards in eight counties were sampled (Table 2). All orchards used for the orchard management and fertility surveys have a history of commercial-level orchard management, and represent a wide range of orchard conditions within the pecan-growing regions of Georgia. Fertility practices varied, but all orchards were managed according to University of Georgia Cooperative Extension recommendations (Wells, 2007). All sampled trees were considered vigorous and in good health. Soil type, orchard floor covering, and irrigation methods of surveyed orchards are presented in Tables 1 and 2 .

Composite samples of 40 leaflet pairs were harvested from 15 random trees in each sampled orchard. Leaf samples were washed in a dilute phosphate-free detergent solution $(0.1 \%$ detergent), followed by rinsing with deionized water. Samples were then dried to a constant weight at $80{ }^{\circ} \mathrm{C}$ and were ground to pass a 20 -mesh screen. Leaves for $\mathrm{N}$ analysis were also ground with mortar and pestle. Samples were analyzed for $\mathrm{N}$ by combustion using a Leco FP528 protein/N determinator (Leco, St. Joseph, MI), whereas remaining nutrients $[\mathrm{Ca}, \mathrm{Mg}$, $\mathrm{K}$, phosphorous $(\mathrm{P}), \mathrm{S}$, boron $(\mathrm{B})$, zinc $(\mathrm{Zn})$, iron $(\mathrm{Fe})$, manganese $(\mathrm{Mn})$, and copper $(\mathrm{Cu})]$ were measured by an inductive coupled plasma spectrophotometer (ICP) coupled to a Digiblock 3000 (SCP Science, Baie D'Urfé, Quebec, Canada).

A composite soil sample at 0 to 6 inches depth with the surface 1 inch removed was taken from under the drip line of the same trees from which leaf samples were taken. Four cores were taken per tree. The soil was dried and analyzed for $\mathrm{pH}, \mathrm{P}, \mathrm{K}, \mathrm{Ca}, \mathrm{Mg}$, $\mathrm{Mn}, \mathrm{Zn}, \mathrm{B}$, and S. In 2008, the soil was also analyzed for carbon (C), nitrate $\left(\mathrm{NO}_{3}\right)$, and soil organic matter $(\mathrm{SOM})$. Soil $\mathrm{pH}$ was determined in a $0.01 \mathrm{M}$ calcium chloride $\left(\mathrm{CaCl}_{2}\right)$ solution using a dual $\mathrm{pH}$ analyzer
(AS-3000; Labfit, Perth, Australia). Soil P, K, Ca, Mg, Mn, Zn, and B were determined by ICP. SOM was determined by the loss on ignition method and is expressed as percentage by weight. Soil $\mathrm{NO}_{3}$ was determined by extraction with $0.1 \mathrm{~N}$ potassium chloride $(\mathrm{KCl})$, and extracts were analyzed colorimetrically. Total $\mathrm{C}$ and $\mathrm{S}$ were analyzed by combustion, converting elemental C and $S$ to carbon dioxide $\left(\mathrm{CO}_{2}\right)$ and sulfur dioxide $\left(\mathrm{SO}_{2}\right)$. The gases were then passed through infrared cells to determine $\mathrm{C}$ and $\mathrm{S}$ content (Kissell and Sonon, 2008).

Analysis of variance (ANOVA) was used to compare soil analyses of orchards using clover as an orchard floor cover with those using a grass sod. Means were separated using Duncan's multiple range test $(P \leq 0.05)$.

\section{Results and discussion}

LEAF ANALYSIs. Average leaf concentrations of all nutrients except $S$ were within or above the recommended leaf sufficiency range during 2005 and 2008. Average leaf N concentration was similar in both years of the study (Table 3). While no orchards were deficient in leaf $\mathrm{N}$ during the 2005 survey, $12 \%$ of mature orchards in the 2008 survey were deficient. The upper and lower ends of the sample range were lower in 2008 than in 2005 as well (Table 3 ). This may have been due to a sharp increase in $\mathrm{N}$ fertilizer prices occurring between 2005 and 2008, and a desire to save input costs by reducing $\mathrm{N}$ application in an anticipated OFF crop in 2008. Additionally, the record-tying 2007 Georgia pecan crop of 150 million pounds (U.S. Department of Agriculture, 2008) may also have somewhat depleted tree $\mathrm{N}$ storage pools.

Leaf $\mathrm{P}$ concentrations from all orchards were within the recommended leaf sufficiency range $(0.12 \%-$ $0.3 \%$ ) during 2005 . The 2008 survey showed leaf P from $12 \%$ of sampled orchards to be lower than the recommended sufficiency range (Table 3 ). Pond et al. (2006) found leaf P from Georgia orchards to be higher than those from Arizona or New Mexico. The authors suggested that because all levels were near the bottom or below recommended ranges (Jones et al., 1991; Robinson et al., 1997), the published ranges for pecans may 
Table 2. Cultivar, orchard age, soil type, irrigation method, and groundcover between tree rows for sampled pecan orchards in 2008 .

\begin{tabular}{llllll}
\hline Orchard & Cultivar & $\begin{array}{c}\text { Age class } \\
\text { (years) }\end{array}$ & Soil type & $\begin{array}{c}\text { Irrigation } \\
\text { method }^{\mathbf{y}}\end{array}$ & $\begin{array}{c}\text { Ground } \\
\text { cover }^{\mathbf{y}}\end{array}$ \\
\hline A & Stuart & $20-30$ & Tifton & Drip & Sod/clover \\
B & Desirable & $30-40$ & Tifton & Drip & Sod/clover \\
C & Schley & $70-80$ & Orangeburg & Drip & Sod \\
D & Schley & $60-70$ & Tifton & Drip & Sod/clover \\
E & Desirable & $40-50$ & Red Bay & SS & Sod/clover \\
F & Desirable & $40-50$ & Fuquay & MJ & Sod \\
G & Desirable & $20-30$ & Lucy Loam & Drip & Sod \\
H & Schley & $60-70$ & Orangeburg & SS & Sod/clover \\
I & Desirable & $20-30$ & Orangeburg & MJ & Sod \\
J & Desirable & $40-50$ & Fuquay & Drip & Sod \\
K & Schley & $60-70$ & Lucy Loam & Drip & Sod/clover \\
L & Sumner & $20-30$ & Tifton & Drip & Sod \\
M & Desirable & $30-40$ & Faceville & Drip & Sod \\
N & Stuart & $30-40$ & Faceville & Drip & Sod \\
O & Desirable & $40-50$ & Faceville & Drip & Sod \\
P & Desirable & $30-40$ & Tifton & Drip & Sod/clover \\
Q & Desirable & $50-60$ & Orangeburg & SS & Sod/clover \\
\hline
\end{tabular}

${ }^{2}$ Drip = drip irrigation, $\mathrm{SS}=$ solid-set sprinkler irrigation, $\mathrm{MJ}=$ microjet sprinkler irrigation

y'Sod $=$ bermudagrass; Clover $=$ crimson clover, ball clover, or 'Durana' white clover.

be too high. Sparks (1989) suggested that $\mathrm{P}$ deficiency can be expected to occur when leaf $\mathrm{P}$ falls below $0.11 \%$, and that maximum nut growth occurred at some point above $0.14 \%$. Leaves are believed to be the principal source from which late season $\mathrm{P}$ demand of developing fruit are met. The fruit's great demand for P late in the growing season can induce leaf necrosis and premature defoliation (Sparks, 1988); however, this was not observed in either year of the survey.

Nutrient deficiency symptoms occur when leaf $\mathrm{K}$ is below $0.70 \%$ (Alben, 1947; Sparks, 1978). The minimum leaf $\mathrm{K}$ recommendation may vary from one geographic region to another. However, Plank (1988) suggests that although good yields can be produced with a minimum leaf $\mathrm{K}$ of $0.75 \%$, leaf $\mathrm{K}$ concentration for optimum production and tree vigor should be maintained between $1.25 \%$ and $2.50 \%$. Wells and Wood (2007) suggested that the leaf $\mathrm{N}: \mathrm{K}$ ratio should be maintained at or near $2: 1$ for optimum yields in the $\mathrm{ON}$ crop year. With an average leaf $\mathrm{N}$ of $2.77 \%$ and $2.65 \%$ for 2005 and 2008, respectively, leaf $\mathrm{K}$ would need to be maintained between $1.3 \%$ and $1.4 \%$. Average leaf $\mathrm{K}$ concentration was $1.26 \%$ and $1.39 \%$ for 2005 and 2008 , respectively. In $2005,45 \%$ of sampled orchards were below the recommended minimum leaf $\mathrm{K}$ of
$1.25 \%$. Only $35 \%$ of sampled orchards were below $1.25 \%$ in 2008 . The upper end of the leaf $\mathrm{K}$ sample range was higher in the 2008 survey than in the 2005 survey (Table 3 ).

Leaf Ca was high in about half the leaf results from sampled orchards in 2005 and in almost $90 \%$ of orchards in 2008. One orchard was low in leaf Ca during 2008 (Table 3). Leaf $\mathrm{Mg}$ was low in $7 \%$ and $6 \%$ of orchards sampled in 2005 and 2008, respectively. Leaf $\mathrm{Mg}$ concentration was high in $12 \%$ of sampled orchards in 2008 (Table 3 ). Leaf Ca is commonly found to be relatively high as a result of the liming of acidic soils on which orchards are grown in most of the southeastern U.S. coastal plain. Dolomitic lime, containing $\mathrm{Mg}$, is often used as the source of liming material in most orchards. As a result, $\mathrm{Mg}$ is rarely deficient in southeastern U.S. orchard trees.

While leaf $S$ concentration was marginal for most orchards during 2005 , leaf $S$ was deficient in only one pecan orchard that year; however, in 2008, leaf $S$ was deficient in almost $90 \%$ of the orchards surveyed. Average leaf $S$ was below the recommended leaf sufficiency range for $S$ in both years of the study (Table 3 ). Southeastern U.S. coastal plain soils on which orchards are established are inherently low in S. In addition, sulfur leaches readily through the soil profile. As a result, $S$ availability does not appear adequate for many southeastern U.S. pecan orchards. Soil S may be immobilized by a variety of factors, including soil organic matter, temperature, moisture, and soil $\mathrm{pH}$. Where immobilization is a problem, foliar S applications may benefit commercial production.

Mean leaf $\mathrm{Fe}$ concentration was adequate in both years of the survey. All sampled orchards were within the recommended leaf sufficiency range in 2005; however, $18 \%$ of sampled orchards had low leaf Fe concentrations in 2008 (Table 3), although no visible symptoms of $\mathrm{Fe}$ deficiency were observed. In Georgia, symptoms of iron chlorosis appear occasionally in commercial orchards, most often in the early spring. However, as soils warm and $\mathrm{Fe}$ becomes more readily available to tree roots, the symptoms are often corrected. Our samples were taken in midsummer, therefore, cold soils should not have led to low leaf $\mathrm{Fe}$. It is unclear why leaf $\mathrm{Fe}$ was low in some orchards. The most likely explanation is the amount of excess $\mathrm{Zn}$ in orchard soils. Metal cations such as $\mathrm{Cu}, \mathrm{Mn}, \mathrm{Zn}$, and molybdenum (Mo) can interact with $\mathrm{Fe}$ to induce such deficiencies in certain situations (Havlin, et al., 2005).

Rosette, or $\mathrm{Zn}$ deficiency, was one of the first major nutritional problems associated with commercial pecan production. As a result, $\mathrm{Zn}$ has been and continues to be commonly applied to most commercial pecan orchards as a foliar spray, via ground application, or both. Mean leaf $\mathrm{Zn}$ concentration was above the recommended sufficiency range in 2005 and only slightly within the upper limit of this range in 2008. Among orchards sampled, $7 \%$ and $2 \%$ were below the recommended leaf concentration for $\mathrm{Zn}$ in 2005 and 2008, respectively, while $34 \%$ and $41 \%$ of orchards were high in leaf $\mathrm{Zn}$ during the same years (Table 3). Most commercial pecan orchards in Georgia have adequate or high leaf $\mathrm{Zn}$ concentrations as a result of multiple years of annual $\mathrm{Zn}$ application.

Foliar B application has been recently shown to increase pecan kernel quality and fruit retention under certain conditions (Wells et al., 2008). Mean leaf B was well within the recommended sufficiency range in 2005 and 2008 (Table 3). Although no orchards were below 


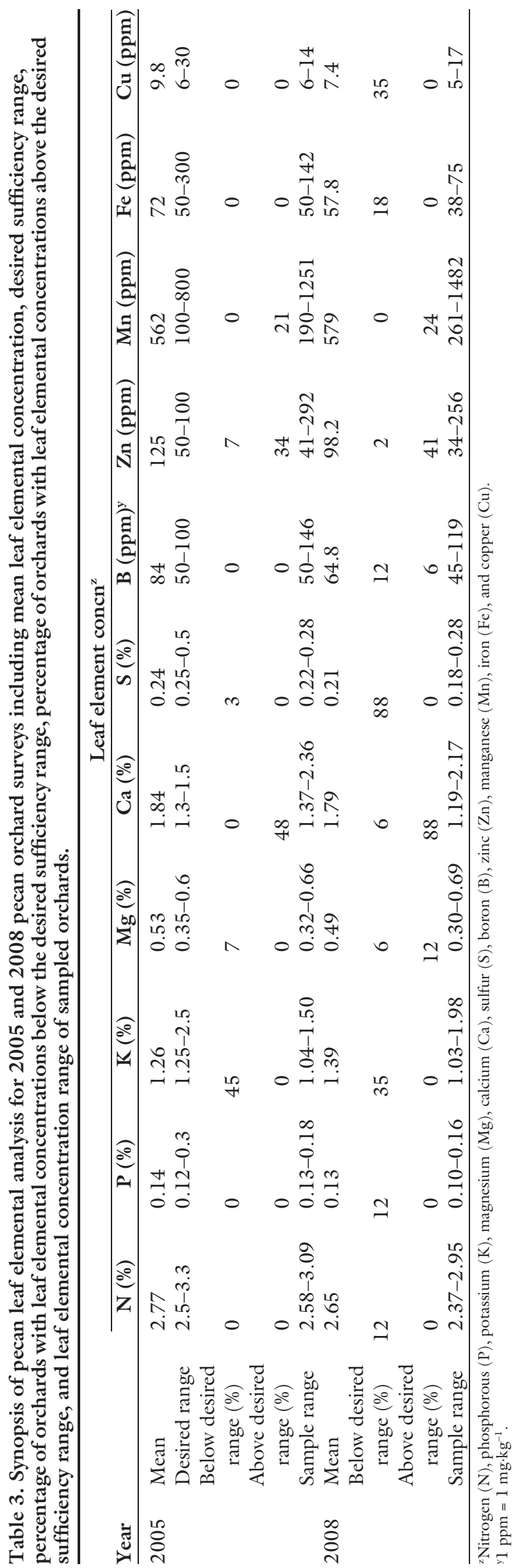

the recommended range in 2005, $12 \%$ of sampled orchards were below the minimum recommended leaf $\mathrm{B}$ concentration in 2008. About 21\% and $6 \%$ of orchards had excessive levels of leaf B in 2005 and 2008, respectively, when compared with the recommended range (Table 3 ). The slightly lower B concentrations observed in 2008 are likely a result of fewer B applications in 2008. Before 2007 , most commercial pecan producers were applying a foliar boron application with each fungicide spray. Since that time, most producers only apply three boron applications per season. Increases in percentage of kernel and fruit retention have been observed with properly timed foliar boron sprays at leaf $B$ concentrations below the current recommended minimum concentration (Wells et al., 2008).

Mean leaf $\mathrm{Cu}$ concentration was within the recommended sufficiency range in both study years (Table 3 ). All orchards were within the recommended range for leaf $\mathrm{Cu}$ in 2005. In 2008 , leaf $\mathrm{Cu}$ was low in $35 \%$ of sampled orchards, while no orchards had leaf sufficiency ranges above the recommended maximum of $30 \mathrm{ppm}$ (Table 3). High soil Zn concentrations can suppress $\mathrm{Cu}$ absorption by roots (Havlin et al., 2005). Because many orchard soils have high $\mathrm{Zn}$ levels, the potential for $\mathrm{Cu}$ deficiency does exist in commercial pecan orchards, especially during the early portion of the growing season.

Mean leaf Mn concentrations were within the recommended leaf sufficiency range in both years of the study (Table 3). While no orchards were below the recommended leaf sufficiency range in either survey year, $21 \%$ and $24 \%$ of orchards had leaf $\mathrm{Mn}$ concentrations higher than the recommended range in 2005 and 2008, respectively (Table 3 ). Manganese deficiency has been reported from Texas (Smith et al., 2001); however, it is rare on the acidic soils of the southeastern U.S. coastal plain.

SoIl ANALYsis. A total of 10 soil types were included in the orchards sampled in both the 2005 and 2008 surveys (Tables 1 and 2). These include Clarendon (fine-loamy, siliceous, thermic Plinthaquic Paleudult), Dothan (fine-loamy, siliceous, thermic Plinthic Paleudult), Faceville (fine, kaolinitic, thermic Typic Kandiudult), 
Table 4. Synopsis of soil elemental analysis and $\mathrm{pH}$ for 2005 and 2008 pecan orchard surveys including mean elemental soil levels, recommended soil sufficiency range, and range of elemental soil levels for sampled orchards.

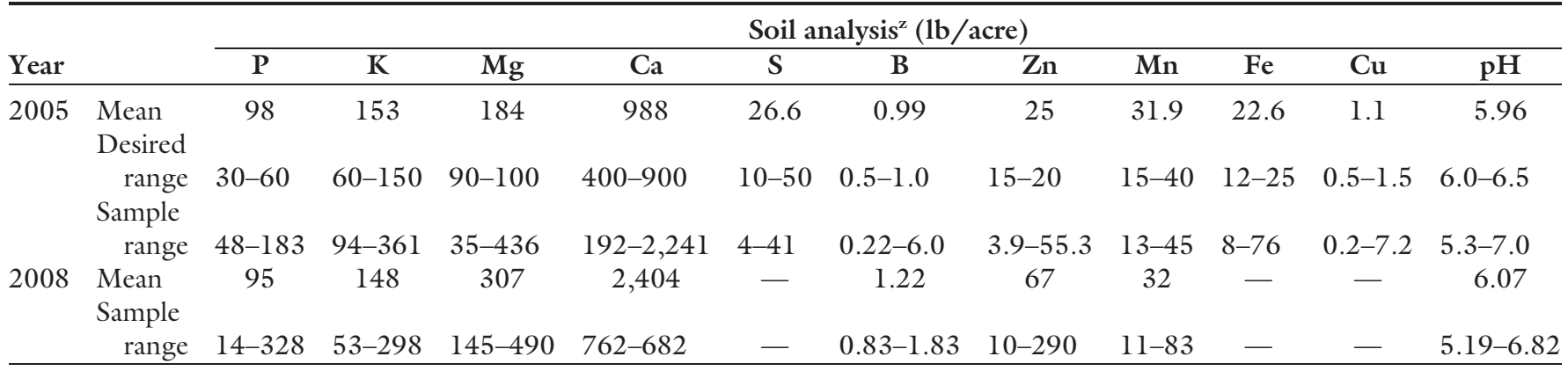

${ }^{2}$ Phosphorous $(\mathrm{P})$, potassium $(\mathrm{K})$, magnesium $(\mathrm{Mg})$, calcium $(\mathrm{Ca})$, sulfur $(\mathrm{S})$, boron $(\mathrm{B})$, zinc $(\mathrm{Zn})$, manganese $(\mathrm{Mn})$, iron $(\mathrm{Fe})$, and copper $(\mathrm{Cu})$

y $1 \mathrm{lb} /$ acre $=1.1209 \mathrm{~kg} \cdot \mathrm{ha}^{-1}$

Fuquay (loamy, sliliceous, thermic Arenic Plinthic Paleudult), Greenville (clayey, kaolinitic, thermic Rhodic Paleudult), Lucy (loamy, siliceous, thermic Arenic Paleudult), Norfolk (fine-loamy, siliceous, thermic Typic Paleudult), Orangeburg (fine-loamy, siliceous, thermic Typic Paleudult), Red Bay (fine-loamy, siliceous, thermic Rhodic Paleudult), and Tifton (fine-loamy, silicieous, thermic Plinthic Paleudult). Skinner et al. (1938) estimated that $95 \%$ of the pecan acreage on the upland soil series was located on Ruston, Norfolk, Tifton, Orangeburg, Greenville, Red Bay, and Cecil soils. About 66\% and $60 \%$ of the soils surveyed in 2005 and 2008, respectively, were among these soil groups (Tables 1 and 2 ).

Soil $\mathrm{pH}$ averaged 5.96 and 6.07 in 2005 and 2008 , respectively (Table 4). In $2005, \mathrm{pH}$ of orchard soils ranged from 5.3 to 7.0 , with $\approx 41 \%$ of orchard soils with a $\mathrm{pH}$ of less than 6.0. The sample range of soil $\mathrm{pH}$ in 2008 was from 5.2 to 6.8 , with a $\mathrm{pH}$ of less than 6.0 in $55 \%$ of sampled orchards. Growth of pecan is sensitive to soil $\mathrm{pH}$. Low soil $\mathrm{pH}$ suppresses root growth (White et al., 1982). Sparks (1989) suggested that pecan orchard soil $\mathrm{pH}$ should be maintained at 6.0 to 6.3 .

Orchard soils averaged 98 and 95 $\mathrm{lb} /$ acre P for 2005 and 2008, respectively (Table 4 ). Uptake of $\mathrm{P}$ may be poor in orchard soils even though soil $\mathrm{P}$ is adequate or high in most orchards. This results from the slow mobility of applied $\mathrm{P}$ on the undisturbed soil surface. For this reason, it can be difficult to raise leaf $\mathrm{P}$ concentration when levels fall below the minimum required. Therefore, soil P should be monitored closely. Foliar fertilization with $\mathrm{P}$ is seldom recommended as a

Table 5. Means and sample ranges for soil carbon $(\mathrm{C})$, soil sulfur $(\mathrm{S})$, soil nitratenitrogen $\left(\mathrm{NO}_{3}-\mathrm{N}\right)$, soil organic matter $(\mathrm{SOM})$, soil $\mathrm{C}: \mathrm{N}$ ratio, and soil $\mathrm{C}: \mathrm{S}$ ratio for the 2008 pecan orchard survey.

\begin{tabular}{|c|c|c|c|c|c|c|}
\hline & \multicolumn{6}{|c|}{ Soil analysis } \\
\hline & $\mathrm{C}(\%)$ & S (\%) & $\mathrm{NO}_{3}-\mathrm{N}(\%)$ & SOM (\%) & $\mathrm{C}: \mathrm{N}$ (ratio) & C:S (ratio) \\
\hline Mean & 2.06 & 0.007 & 14.05 & 3.63 & $13: 1$ & $504: 1$ \\
\hline $\begin{array}{l}\text { Sample } \\
\text { range }\end{array}$ & $1.12-3.96$ & $0.001-0.01$ & $3.5-44.26$ & $1.74-5.80$ & $12: 1-16: 1$ & $95: 1-1600: 1$ \\
\hline
\end{tabular}

substitute for soil fertilization practices, due in large part to the inconsistent response of crops to foliar P (Barker and Pilbeam, 2007).

Surveyed orchards averaged 153 $\mathrm{lb} /$ acre K in 2005 and $148 \mathrm{lb} /$ acre K in 2008. Soils ranged from 94 to 361 $\mathrm{lb} /$ acre K in 2005 and from 53 to 298 $\mathrm{lb} /$ acre in 2008 (Table 4). Orchards with soil levels below $100 \mathrm{lb} /$ acre K were found on soils with a higher sand content. $\mathrm{K}$ is easily lost to leaching when soil pH falls below 6.0 (Sparks, 1989). Klevels were high in some clay soils and still relatively low in leaf samples, indicating a lack of available $\mathrm{K}$ in those soils. $\mathrm{K}$ tends to hold tightly to clay particles, making soil K unavailable to plants.

Orchard soils averaged $988 \mathrm{lb} /$ acre $\mathrm{Ca}$ and $2404 \mathrm{lb}$ /acre Ca in 2005 and 2008, respectively (Table 4). Many pecan orchards in the southeastern U.S. coastal plain have high soil $\mathrm{Ca}$ levels as a result of liming. Mean soil level averaged $184 \mathrm{lb} /$ acre $\mathrm{Mg}$ in 2005 and $307 \mathrm{lb} /$ acre $\mathrm{Mg}$ in 2008 (Table 4). As mentioned earlier, dolomitic lime is commonly used to raise soil $\mathrm{pH}$ of most orchard soils. As a result, most Georgia pecan orchard soils are rarely deficient in $\mathrm{Mg}$. Sparks (1989) suggests that replacing dolomitic lime with calcitic lime when leaf $\mathrm{Mg}$ reaches $0.45 \%$ or greater can help to minimize the effect of $\mathrm{Mg}$ on Kuptake.
In 2005, orchard samples had a mean of $26.6 \mathrm{lb} /$ acre $S$, with levels ranging from 4 to $4 \mathrm{llb} /$ acre $S$ (Table 4 ). Soil $S$ was measured as percentage of total $S$ in the 2008 survey. In 2008, the percentage of total $S$ averaged $0.007 \%$, and ranged from $0.001 \%$ to $0.01 \%$ (Table 4 ). As mentioned earlier, southeastern U.S. coastal plain soils contain low natural levels of $S$, which leaches readily from the sandy and sandy loam soils found throughout the region. In the humid conditions of the southeastern United States, $\approx 90 \%$ of total $S$ is found in organic matter (Havlin et al., 2005). Therefore, much of the $S$ that does not leach from the soil is bound in organic matter and thus is likely to be unavailable to the trees. Soil C:S ratio may also influence the availability of $S$ to plants. The mean C:S ratio of Georgia pecan orchard soils was 504:1 (Table 5), which may further explain the low leaf $S$ concentration observed here in the face of low soil $S$ levels. Sulfur is generally immobilized in soils with a C:S ratio $>400: 1$ (Havlin et al., 2005), even at adequate soil $S$ levels.

Soil $\mathrm{Fe}$ was not measured in 2008; however, 2005 orchard samples revealed a mean of $22.6 \mathrm{lb} /$ acre $\mathrm{Fe}$, with samples ranging from 8 to 76 $\mathrm{lb} /$ acre (Table 4). Soil pH in orchards with low leaf $\mathrm{Fe}$ was above 6.0, 
therefore, low leaf Fe could have been related to high soil $\mathrm{pH}$.

Soils averaged $25 \mathrm{lb} /$ acre $\mathrm{Zn}$ and $67 \mathrm{lb} /$ acre $\mathrm{Zn}$ in 2005 and 2008, respectively. The sample ranges were much higher in 2008 than in 2005 (Table 4). Because most pecan producers are aware that $\mathrm{Zn}$ deficiency is the most well-known micronutrient deficiency of pecan, it is not surprising that soil $\mathrm{Zn}$ levels would be relatively high in many commercial orchards. This likely results from multiple $\mathrm{Zn}$ applications over many years. Although liming of an acid soil can reduce $\mathrm{Zn}$ availability (Hunter, 1965), tree Zn needs can usually be maintained if foliar $\mathrm{Zn}$ is also applied (Brooks, 1964; Hunter, 1965). Most forms of $\mathrm{Zn}$ become relatively immobile soon after soil application. As a result, soil applied $\mathrm{Zn}$ is often slow to move into the tree, sometimes taking as much as three years before an increase in leaf $\mathrm{Zn}$ is observed (Hunter, 1965).

Soils averaged $0.99 \mathrm{lb} /$ acre B in 2005 and $1.22 \mathrm{lb} /$ acre $B$ in 2008 (Table 4). Coarse-textured, welldrained soils are generally low in B. In addition, $\mathrm{B}$ is highly mobile in the soils of the southeastern U.S. coastal plain. Less than $5 \%$ of total soil $B$ is available to plants (Havlin et al., 2005). Orchard soils in 2005 averaged $1.1 \mathrm{lb} / \mathrm{acre} \mathrm{Cu}$, and ranged from 0.20 to $7.2 \mathrm{lb} /$ acre $\mathrm{Cu}$ (Table 4). Soil $\mathrm{Cu}$ was not measured in 2008. The $\mathrm{Cu}$ requirements of pecan have been poorly studied; however, requirements are believed to be relatively low, with a minimum leaf $\mathrm{Cu}$ sufficiency concentration of only $6 \mathrm{ppm}$. Still, as mentioned previously, in 2008, $35 \%$ of sampled orchards were marginally low in leaf $\mathrm{Cu}$ (Table 3 ). The potential for $\mathrm{Cu}$ deficiency is highest in coarse-textured soils with high levels of $\mathrm{Zn}, \mathrm{Fe}$, and $\mathrm{P}$ (Havlin et al., 2005). Average Soil Mn levels were identical in 2005 and 2008 (Table 4).

Organic matter levels of pecan orchard soils have received little attention in the literature. This is surprising, in light of the valuable role played by SOM and the attention it has received regarding its contributions to agricultural productivity. Sparks (2005) suggests that the humus-topsoil-root association is key to the overall nutrition of pecan in nature via nutrient recycling, mainly from decaying leaves and shucks. SOM of Georgia pecan orchards from the 2008 survey averaged $3.63 \%$ (Table 5), and ranged from $1.74 \%$ on coarse-textured sandy soils to over $5 \%$ on sandy loam soils. Most Georgia soils vary in organic matter content from $0.5 \%$ to $2.0 \%$ (Kissell and Sonon, 2008). The warm, humid climate typical of the region is conducive to microbial activity during much of the year, preventing extensive accumulation of SOM. Consequently, SOM rarely exceeds 3\% (Giddens, 1957). The relatively high level of shallow subsurface SOM from pecan orchards is comparable to that of natural hardwood forests occurring within the Georgia coastal plain (Giddens, 1957; M.L.Wells, unpublished data), and higher than that observed on row crop fields (Giddens, 1957). The high level of SOM found in pecan orchard soils is a result of the annual addition of leaves, shucks, and woody debris to the surface of orchard soils and the decomposition of this material. It is likely that SOM would be lower in the vegetation-free herbicide strips than was found between tree rows.

Soil $\mathrm{NO}_{3}$ levels averaged $14.05 \%$ (Table 5 ), and ranged from $3.5 \%$ on sandy soils to $44 \%$ on loamy soils. Orchard soil C averaged 2.05\%, ranging from $1.12 \%$ to $3.96 \%$ (Table 5 ). Skinner (1924) reported an average soil C percentage of $1.5 \%$ for orchards in Alabama. Most southeastern U.S. pecans at the time of Skinner's study were grown under clean cultivation and were usually disked at least once per year, which may explain the reduced soil C levels at shallow soil depths compared with the current study.

Soil C: $\mathrm{N}$ ratio affects $\mathrm{N}$ availability, total organic matter, and the rate of organic decay. For this reason, it is considered a highly valuable factor in developing sound soil management schemes (Brady, 1974). Orchard floor covers using organic materials with low C:N ratios of $15: 1$ to $20: 1$, such as legumes, will release $\mathrm{N}$ more rapidly, whereas materials with high C:N ratios of $40: 1$ to $80: 1$, such as grasses, may actually immobilize $\mathrm{N}$ during their decomposition before it would become available to tree roots. Mean C:N ratio of pecan orchard soils was $\approx 13: 1$, and ranged from 12:1 to 16:1 (Table 5). Lewis and Hunter (1940) reported a more narrow C:N ratio of $8: 1$ on southeastern U.S. coastal plain soils on which cotton
(Gossypium hirsutum) and corn (Zea mays) were grown.

Crimson clover (Triflolium incarnatum), 'Durana' white clover (Trifolium repens), or ball clover (Trifolium nigrescens) were used as orchard floor covers on nearly $15 \%$ of surveyed orchards in 2005, and on $47 \%$ of orchards in 2008 (Tables 1 and 2). SOM and soil $\mathrm{NO}_{3}$ were higher in orchards using clover and sod as a cool season orchard floor covering than those using sod only (Fig. 1). Skinner et al. (1938) reported an increase in SOM where kudzu (Pueraria montana), velvetbeans (Mucuna pruriens), austrian winter peas (Pisum sativum), or rye (Secale cereale) were used as winter cover crops in pecan orchards; however, soil $\mathrm{N}$ was maintained at about the same level as the control. Smith, et al. (1996) reported occasionally higher soil $\mathrm{NO}_{3}$ levels with a legume/bermudagrass (Cynodon dactylon) cover crop than for bermudagrass and Marchapplied $\mathrm{N}$ for orchards in Oklahoma. Ware and Johnson (1958) also suggested that orchard soils on which winter legumes were cut and left on the soil surface had nitrate levels that increased later in the season and were higher than control plots. No differences in soil $\mathrm{C}$ or soil C:N ratio were observed between orchards with clover as a floor covering and those with only sod in the current study. Skinner et al. (1938) suggested that use of a soluble commercial $\mathrm{N}$ fertilizer in conjunction with a green manure crop maintained a lower soil C:N ratio, resulting in a higher level of soil fertility.

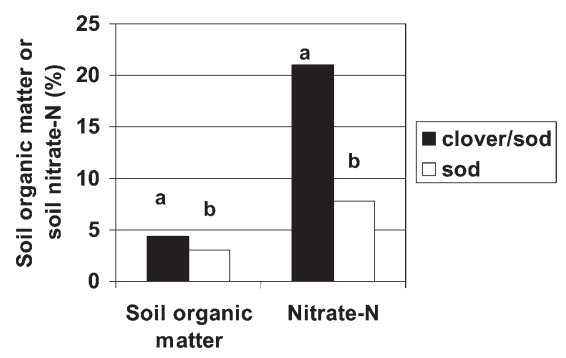

Fig. 1. Soil organic matter (SOM) and soil nitrate-nitrogen $(\mathrm{N})$ levels of pecan orchard soils utilizing clover (crimson clover, ball clover, or 'Durana' white clover) and sod (bermudagrass) or sod only as an orchard floor covering in 2008. Columns with different letters are significant according to analysis of variance at $P<0.05$. 
In conclusion, many southeastern U.S. pecan producers could likely reduce input costs by applying only those nutrients required according to the results of annual leaf and soil analysis. The results presented here suggest that the greatest potential for nutrient deficiencies in the region currently exist with $\mathrm{N}, \mathrm{K}, \mathrm{S}$, and $\mathrm{Cu}$ compared with $\mathrm{P}, \mathrm{Ca}, \mathrm{Mg}, \mathrm{Fe}, \mathrm{Mn}$, and $\mathrm{B}$. Nitrogen is the most important nutrient required for tree growth and nut production. Due to the wide variability among locations and years, practitioners should closely monitor leaf $\mathrm{N}$ concentration of commercial orchards. It is apparent that utilization of clover in combination with grass sod on orchard floors can enhance the availability of $\mathrm{N}$ to pecan trees. Although there was no difference in leaf $\mathrm{N}$ between orchards with and without clover, midsummer soil $\mathrm{NO}_{3}$ levels were higher where clover was grown. This suggests that utilization of clover in orchards can reduce $\mathrm{N}$ applied to orchards, leading to considerable savings for producers. These results agree with Smith et al. (1996), who demonstrated that $\mathrm{N}$ fixed by clover can meet much of the $\mathrm{N}$ demand by pecan trees in Oklahoma. Pecan orchard soils also maintain relatively high levels of SOM, which appears to be enhanced with the addition of clover as an orchard floor cover. A relatively high percentage of the region's pecan orchard soils have low soil $\mathrm{pH}$. Producers should be aware of the value of maintaining soil $\mathrm{pH}$ in the range of 6.0 to 6.5. However, because $\mathrm{Ca}$ and $\mathrm{Mg}$ levels where high in leaf and soil samples from many orchards, producers may want to continue applying lime only when soil analysis indicates a low $\mathrm{pH}$. Also, it would appear that many growers could likely forego the soil application of $\mathrm{P}$ and $\mathrm{Zn}$ until leaf or soil analysis indicates a need, as long as foliar $\mathrm{Zn}$ applications are applied as recommended.

\section{Literature cited}

Acuna-Maldonado, L.E., M.W. Smith, N.O. Maness, B.S. Cheary, and B.L. Carroll. 2003. Influence of nitrogen application time on nitrogen absorption, partitioning, and yield of pecan. J. Amer. Soc. Hort. Sci. 128:155-162.

Alben, A.O. 1947. Analysis of pecan leaves as an aid in fertility studies. Proc. Oklahoma Pecan Growers Assn. 17:38-45.
Barker, A.V. and D.J. Pilbeam. 2007. Handbook of plant nutrition. CRC Press, Boca Raton, FL.

Brady, N.C. 1974. The nature and properties of soils, 8 th ed. Macmillan. New York.

Brooks, O.L. 1964. Yield response of Stuart pecan to zinc sulfate. Proc. Southeastern Pecan Growers Assn. 57:23-25.

Giddens, J. 1957. Rate of loss of carbon from Georgia soils. Soil Sci. Soc. Amer. Proc. 21:513-515.

Havlin, J.L., J.D. Beaton, S.L. Tisdale, and W.L. Nelson. 2005. Soil fertility and fertilizers. Pearson Prentice Hall, Upper Saddle River, NJ.

Hunter, J.H. 1965. Effects of lime and zinc on the $\mathrm{pH}$ of soil, yield of pecans, and zinc content of leaves. Proc. Southeastern Pecan Growers Assn. 58:6-11.

Johnson, G.V. and W.R. Raun. 2003. Nitrogen response index as a guide to fertilizer management. J. Plant Nutr. 26:249-262.

Jones, J.B., Jr., B. Wolf, and H.A. Mills. 1991. Plant analysis handbook. MicroMacro Publishing, Athens, GA.

Kissell, D.E. and L. Sonon. 2008. Soil test handbook for Georgia. Univ. Georgia Coop. Ext. Special Bul. 62.

Kraimer, R.A., W.C. Lindemann, and E.A. Herrera. 2001. Distribution of ${ }^{15} \mathrm{~N}$ labeled fertilizer applied to pecan: A case study. HortScience 36:308-312.

Kraimer, R.A., W.C. Lindemann, and E.A. Herrera. 2004. Recovery of lateseason ${ }^{15} \mathrm{~N}$-labeled fertilizer applied to pecan. HortScience 39:256-260.

Lewis, R.D. and J.H. Hunter. 1940. The nitrogen, organic carbon, and $\mathrm{pH}$ of southeastern coastal plain soils as influenced by green manuring crops. J. Amer. Soc. Agron. 32:586-601.

Plank, C.O. 1988. Plant analysis handbook for Georgia. Georgia Coop. Ext. Serv., Athens.

Pond, A.P., J.L. Walworth, M.W. Kilby, R.D. Gibson, R.E. Call, and H. Nunez. 2006. Leaf nutrient levels for pecans. HortScience 41:1339-1341.

Robinson, J.B., M. Treeby, and R.A. Stephenson. 1997. Fruits, vines, and nuts, p. 347-382. In: D.J. Reuter and J.B. Robinson (eds.). Plant analysis, an interpretation manual, CSIRO Publishing, Collingwood, Victoria, Australia.

Skinner, J.J. 1924. Influence of soil type on the yield and quality of pecans. Agron. J. 16:51-57.

Skinner, J.J., E.D. Fowler, and A.O. Alben. 1938. Pecan soils of the gulf and southern states and maintenance of their fertility. U.S. Dept. Agr. Circ. 492.

Smith, M.W. 1991. Pecan nutrition, p. 152158. In: B.W. Wood and J.A. Payne (eds.). Pecan husbandry: Challenges and opportunities. National Pecan Workshop Proc., U.S. Dept. Agr., Agr. Res. Serv., ARS-96.

Smith, M.W., A. Shiferaw, and N.R. Rice. 1996. Legume cover crops as a nitrogen source for pecan. J. Plant Nutr. 19:11171130.

Smith, M.W., B.S. Cheary, and B.S. Landgraf. 2001. Manganese deficiency in pecan. HortScience 36:1075-1076.

Smith, M.W., C.T. Rohla, and N.O. Maness. 2007. Correlations of crop load and return bloom with root and shoot concentrations of potassium, nitrogen, and nonstructural carbohydrates in pecan. J. Amer. Soc. Hort. Sci. 132:44-51.

Sparks, D. 1978. Nutrient concentrations of pecan leaves associated with deficiency symptoms and normal growth. HortScience 13:256-257.

Sparks, D. 1988. Growth and nutritional status of pecan in response to phosphorous. J. Amer. Soc. Hort. Sci. 113:850-859.

Sparks, D. 1989. Pecan nutrition: A review. Proc. Southeastern Pecan Growers Assn. 82:101-122.

Sparks, D. 2005. Adaptability of pecan as a species. HortScience 40:1175-1189.

U.S. Department of Agriculture. 2008. Noncitrus fruits and nuts: 2007 summary. Natl. Agr. Stat. Serv., U.S. Dept. Agr, Washington, DC.

Ware, L.M. and W.A. Johnson. 1958. Certain relationships between fertilizer and cultural practices, nitrate and moisture content of the soil, and response of pecan trees. Proc. Southeastern Pecan Growers Assn. 51:10-17.

Wells, L. 2007. Southeastern pecan growers handbook. Univ. Georgia Coop. Ext. Bul. 1327.

Wells, M.L. and B.W. Wood. 2007. Relationships between leaflet nitrogen: potassium ratio and yield of pecan. HortTechnology 43:473-479.

Wells, M.L., P.J. Conner, J.F. Funderburk, and J.G. Price. 2008. Effects of foliar boron on fruit retention, fruit quality, and tissue boron concentration of pecan. HortScience 43:696-699.

White, A.W., E.R. Beaty, and W.L. Tedders. 1982. Legumes as a source of nitrogen and effects of management practices on legumes in pecan orchards. Proc. Southeastern Pecan Growers Assn. 74: 97-106. 